\title{
Status of Community Drinking Water in Korea and Implications for Appropriate Management
}

\author{
Jin-Yong Lee ${ }^{1 *} \cdot$ Youngyun Park $^{1} \cdot$ Nam-Ju Kim ${ }^{1,2} \cdot$ Woo-Hyun Jeon $^{1}$ \\ ${ }^{1}$ Department of Geology, College of Natural Sciences, Kangwon National University, Chuncheon 200-701, Korea \\ ${ }^{2}$ Geo Engineering Co., Ltd., ITECO 639, Hanam 465-013, Korea
}

\begin{abstract}
Community drinking water (CDW), mostly naturally flowing groundwater, plays important roles in supplying drinking water for urban and rural residents in Korea. Over 1,600 CDW facilities are distributed throughout the country, many of them situated in the outskirts of metropolitan cities. A large proportion of Korean people have become dependent on CDW for drinking due to a distrust of piped water's quality and a strong belief in the special medicinal effects of some CDWs. However, administrative and official management and the control of CDW facilities have been inadequate when compared with the strict examination and control of commercial bottled water, which is physically treated groundwater from deep bedrock aquifers. In this study, even though signs of anthropogenic contamination were not generally found, the tested chemical compositions of selected CDWs featured high enrichment of some constituents including $\mathrm{Ca}, \mathrm{Mg}, \mathrm{Na}$, and $\mathrm{HCO}_{3}$ with natural origins such as water-rock interactions. Careless consumption of particular CDWs, which has no scientific basis, will not guarantee health improvement. Consequently, more intensive management of CDW facilities and a long-term interdisciplinary examination of the health effects of CDWs are needed to effectively protect people's health.
\end{abstract}

Key words : Community drinking water, Yaksu (medical water), Carbonate, Iron, Anthropogenic contamination

\section{Introduction}

The Republic of Korea (hereafter Korea) is one of the most rapidly developing countries. With this economic development, the needs and interests of the people with respect to healthful foods and a clean environment, including clean water and air, have increased dramatically. Consumers readily pay higher costs for environment-friendly agricultural products (no pesticides or artificial fertilizers applied) and for commercial bottled water (domestic or imported) instead of tap water from urban/municipal water works. Frequent river water contamination accidents due to wastewater effluents (Ko et al., 2007; Sim et al., 2010) have aggravated public skepticism about the quality of tap water sourced from rivers. Most Koreans buy bottled water for drinking; only poor people drink tap water, and then only after boiling. After the commercial sales of bottled water or mineral water (only permitted if it is pumped groundwater) was officially permitted in 1995, its domestic sales rose significantly from \$264 million in 2005 to \$661 million in 2012 , reflecting an annual growth rate of over $10 \%$.

In addition to bottled water, community drinking water (CDW) facilities, defined as naturally flowing water, springs, or developed wells for supplying drinking water to the public, called "Yaksu" in Korean (Lee, 2013), have been gaining popularity over the years. Many Koreans believe that Yaksu has medical value or mysterious effectiveness for healing certain diseases. These CDW facilities (over 1,600 facilities throughout the country; Fig. 1) have been managed according to the Management of Drinking Water Act (No. 11663) enacted in 1995 (Lee, 2013). However, although commercially sold bottled water has been strictly regulated by a relevant governmental authority (Ministry of Environment) under the same law, through a tough environmental impact assessment during the development permit stage, very frequent water quality tests (Table 1) during the pro-

*Corresponding author : hydrolee@kangwon.ac.kr

Received : 2013.10.11 Reviewed :2013.10.15 Accepted:2013.10.15

Discussion until : 2013.1.31 
Table 1. Summary of water quality tests for commercial bottled water, enforced by a relevant Korean law

\begin{tabular}{clc}
\hline \hline No. of parameters & Test parameters & Frequency \\
\hline 5 & Odor, taste, color, turbidity, pH & Every day \\
4 & $\begin{array}{l}\text { Total colony counts (psychrophilic and mesophilic bacteria), Total coliforms, } \\
\text { Pseudomonas aerugino }\end{array}$ & Two times per week \\
4 & $\begin{array}{l}\text { Fecal streptococci, Sulfate reducing spore forming anaerobe, Salmonella spp., Shigella spp. Every month } \\
57\end{array}$ & $\begin{array}{l}\text { Totally } 57 \text { parameters including microbes, inorganic substances, organic compounds, } \\
\text { disinfectants and above parameters }\end{array}$ \\
\hline
\end{tabular}

Table 2. Summary of water quality tests for community drinking water facility

\begin{tabular}{clc}
\hline \hline $\begin{array}{c}\text { No. of } \\
\text { parameters }\end{array}$ & Test parameters & Quarter \\
\hline 7 & $\begin{array}{l}\text { Total colony counts, Total coliforms, Escherichla coli, } \mathrm{NH}_{3}-\mathrm{N}, \mathrm{NO}_{3}-\mathrm{N}, \mathrm{KMnO}_{4} \text { consumption, total solids } \\
\text { Totally } 48 \text { parameters including microbes, inorganic substances, organic compounds, disinfectants and above } \\
\text { parameters }\end{array}$ & $\begin{array}{c}1 / 4,3 / 4,4 / 4 \\
2 / 4\end{array}$ \\
\hline
\end{tabular}

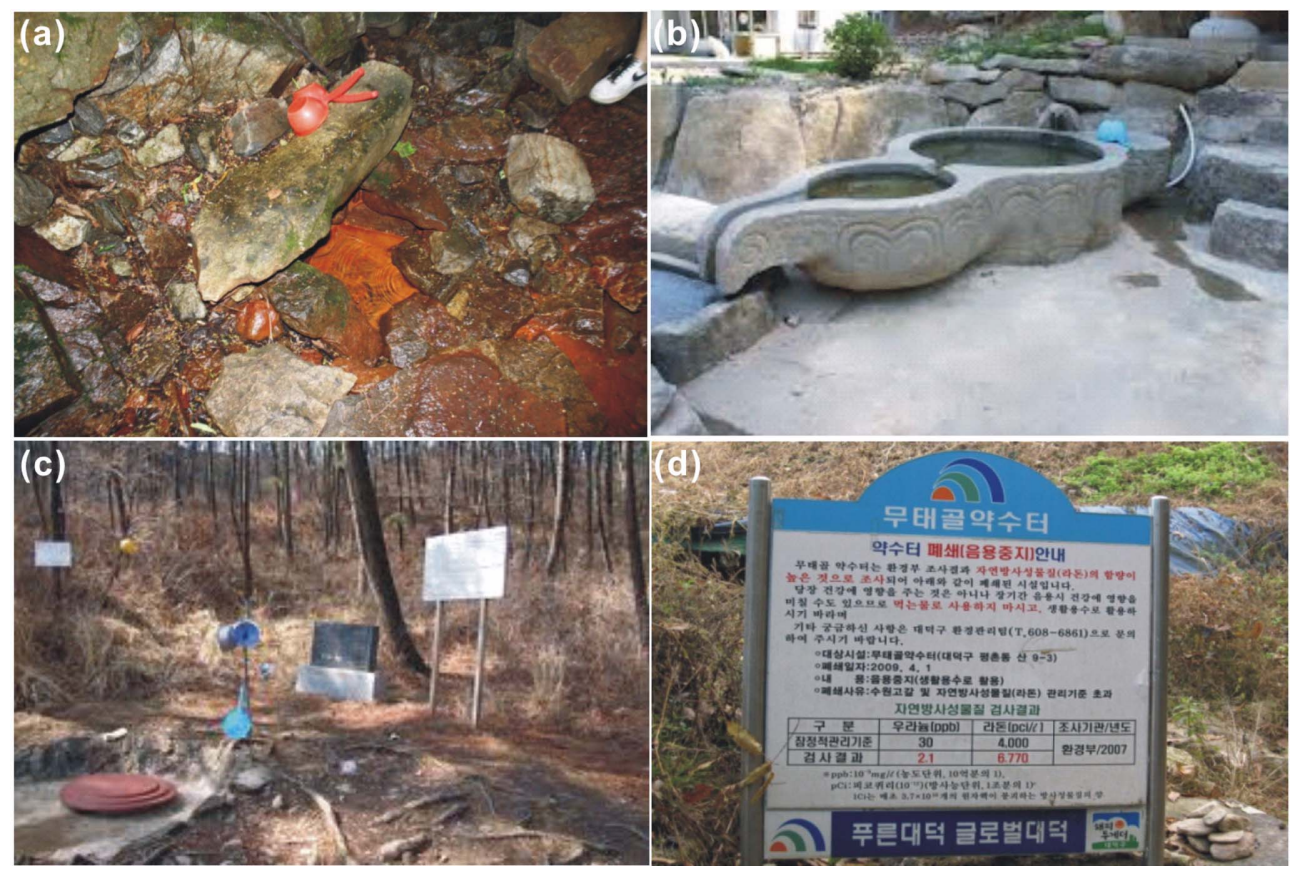

Fig. 1. Scenes of community drinking water facilities and some of them have been suffered from contamination.

duction stage, and taxation on its dissemination, the control of CDW has been somewhat loose and arbitrary.

Local governments (county level) have been conducting water quality testing for each CDW facility (Table 2). The parameters for the quarterly $\left(1^{\text {st }}, 3^{\text {rd }}\right.$, and $\left.4^{\text {th }}\right)$ tests include total colony counts, total coliforms, Escherichla coli, $\mathrm{NH}_{3}-\mathrm{N}$, $\mathrm{NO}_{3}-\mathrm{N}, \mathrm{KMnO}_{4}$ consumption, and total solids (generally excluded in the test). In the second quarterly test, the number of the examining parameters increases to 48 , including the above parameters. If the water quality of the CDW facil- ity exceeds the standards, the local government issues a notice (a warning poster) to persuade people to stop using the water (facility) for drinking purposes (see Fig. 1(d)). However, this passive measure cannot deter local people from seeking and consuming the water (Lee, 2013). Furthermore, because many CDW (Yaksu) facilities are located in somewhat remote areas (mostly in the mountains) far from main residential areas, administrative measures, including water quality testing and bans on its use, are not effective.

The most popular Yaksu (CDW) in the country has abnor- 


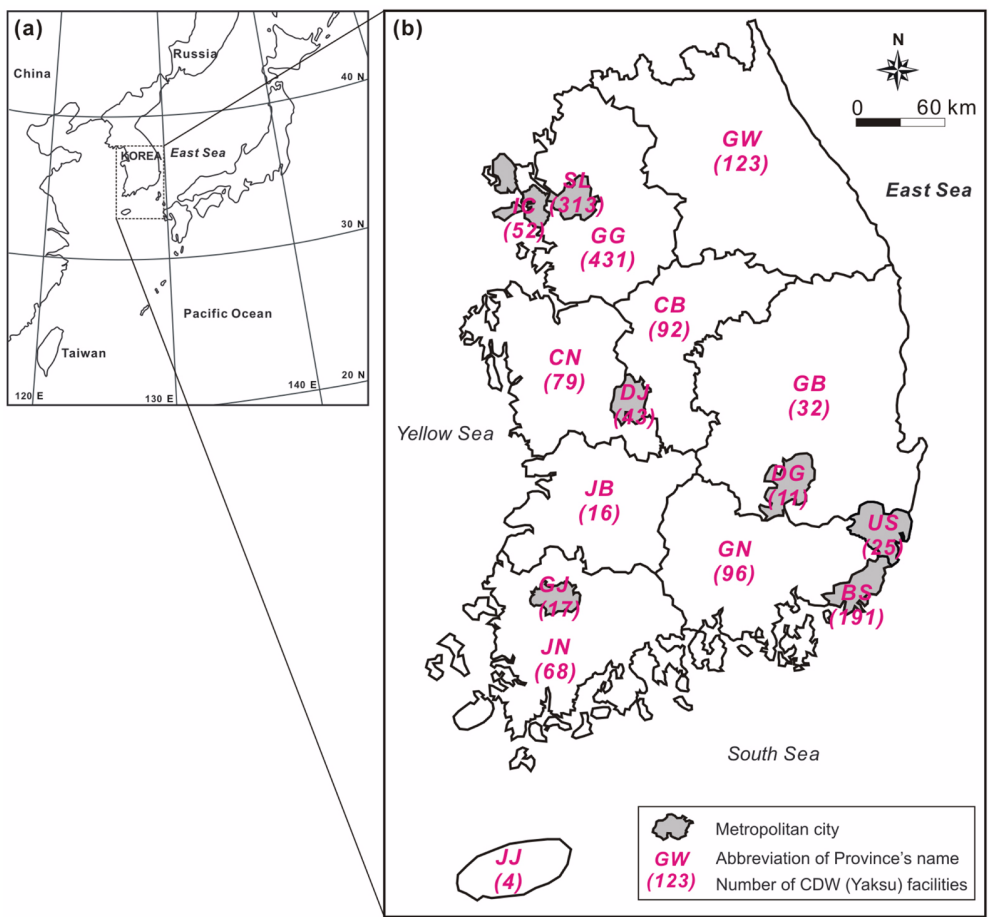

Fig. 2. Location of the study area (Korea) showing the number of community drinking water (CDW) facilities as of 2009.

mally high levels of constituents such as metals ( $\mathrm{Fe}$ and $\mathrm{Mn}$ ) and (bi)carbonate $\left(\mathrm{HCO}_{3}\right)$ (Koh et al., 2000). This quality (sometimes accompanied by an unpleasant smell and taste) attracts people who believe that this water has a special medical effectiveness for some diseases. However, verification of this medical effectiveness has been rare (Lee, 2013), and this water source has often suffered from natural and anthropogenic contamination due to the absence of appropriate maintenance. The most frequent problematic parameters among CDW include microbes (total colony counts, total coliforms, and fecal coliforms), nitrate, and iron. Although some cations $(\mathrm{Ca}, \mathrm{Mg}, \mathrm{Na}, \mathrm{K})$ and anions $\left(\mathrm{HCO}_{3}{ }^{-}, \mathrm{CO}_{3}{ }^{2-}\right)$ may be greatly enriched in some of these sources, they are not generally controlled because they are not listed in Korean drinking water standards.

The objective of this study was to examine the chemical characteristics of CDW facilities throughout Korea with the aim of arriving at some implications and recommendations for proper management. For this purpose, we collected basic information (location and distribution) of the CDW facilities from the Ministry of Environment and chemistry data from the Korean scientific literature.

\section{Methods and Materials}

\subsection{Study Area}

Korea is located in southern part of the Korean peninsula and has an area of $99,601 \mathrm{~km}^{2}$; it is surrounded by water on three sides (Fig. 2(a)). The population of the country was approximately 50 million in 2012, reflecting a population density of 502 people $/ \mathrm{km}^{2}$. However, the population density is much greater in the metropolitan cities (grey colored areas in Fig. 2(b)), ranging from 12,000 (Ulsan) to 18,000 people/ $\mathrm{km}^{2}$ (Seoul). Approximately $75 \%$ of the country is mountainous, and topographic elevations are high in the east (500$1,000 \mathrm{~m}$ ) and low in the west $(<100 \mathrm{~m})$ (Lee et al., 2007). Thus, paddy and vegetable fields are mostly distributed in the west, with forests in the east.

The climate of Korea is characterized by the East Asian monsoon and has four distinct seasons (Lee and Lee, 2000; Seo and Ok, 2013). The annual mean air temperature from 1981-2010 was $10-15^{\circ} \mathrm{C}$, with the highest temperatures occurring in August $\left(23-26^{\circ} \mathrm{C}\right)$, and the lowest in January $\left(-6-3^{\circ} \mathrm{C}\right)$ (KMA, 2013). The annual precipitation ranges from 1,000 to $1,900 \mathrm{~mm}$, with an increasing trend due to climate change, and over $60 \%$ of the total precipitation occurs 
in the summer (June-August) (Lee et al., 2012). Recently, increases in annual precipitation have been concentrated in the wet season, and heavy rainstorms are therefore more frequent in this season (Jung et al., 2013).

The geology of Korea comprises mainly Precambrian gneiss and Jurassic granite in the middle part, and Cretaceous sedimentary rocks in the southern part. Quaternary volcanic rocks are only found at Jeju Island and Ulleung-do (Lee et al., 2007). In the central part, a zone of highly metamorphosed rocks, governed by thrusts and folds and with a band width of $70 \mathrm{~km}$, is distributed from southwest to northeast, extending 400 km (Choi et al., 2012; Moon et al., 2013). Carbonate rocks are mainly distributed in this zone, especially in Gangwon Province (GW area in Fig. 2; Park et al., 2011a).

Annual water use in Korea is 33.3 billion $\mathrm{m}^{3}$, of which $32.4,56.4$, and $11.2 \%$ are obtained from rivers, dams, and groundwater, respectively (GIMS, 2013). Among the total annual groundwater use $\left(3.7\right.$ billion $\left.\mathrm{m}^{3}\right)$, agricultural and domestic use account for 48.9 and $46 \%$, respectively, while other uses such as hot springs and bottled water represent only 5.1\% (GIMS, 2013). There are approximately 1.44 million groundwater wells in Korea, resulting in well density of 14.5 wells $/ \mathrm{km}^{2}$. Although most urban areas are serviced by waterworks (97.6-99.1\%), urban residents generally depend on bottled water or CDW (Yaksu) as a drinking water source because they doubt the quality of piped municipal water (chemically treated river water).

\subsection{Data Collection}

The location data (coordinates) of officially reported CDW facilities were obtained from an open access site (Institute of Health and Environment of Gyeonggi Province; http://gihe.gg.go.kr). Additionally, water quality data for these facilities $(n=236$, mainly chemical compositions) were collected from various sources in the published literature, including Kim et al. (1998) (number of data set, $n=47$ ), Moon and Park (1998) $(\mathrm{n}=47)$, Jeong and Jeong (1999) $(\mathrm{n}=7)$, Koh et al. (2000) $(\mathrm{n}=19), \mathrm{Kim}$ et al. (2001) $(n=14)$, Jeong et al. (2002) $(n=31)$, Kim et al. (2002) $(n=51)$, Jeong et al. (2011) $(n=11)$, and Jeong et al. (2012) $(\mathrm{n}=9)$. Concentration units were adjusted to $\mathrm{mg} / \mathrm{L}$ for further analysis, but the charge balance was not checked due to some missing data in each data set (parameters not ana- lyzed). The geology around CDW facilities included in this study was mostly biotite granite or gneiss and partly sedimentary rocks.

\section{Results and Discussion}

\subsection{Distribution of CDW (Yaksu) Facilities}

Fig. 2(b) shows the distribution of CDW facilities throughout the country. With respect to the administrative province, the number of CDW facilities is greater in the order Gyeonggi (GG) Province $>$ Seoul $(\mathrm{SL})>$ Busan $(\mathrm{BS})>$ Gangwon Province (GW). However, the number per unit area is Seoul $(\mathrm{SL})>$ Busan $(\mathrm{BS})>$ Daejeon $(\mathrm{DJ})>$ Incheon (IC). These statistics indicate that the CDW facilities are mostly placed in urban areas with high populations. This is somewhat ironic because metropolitan areas are the best serviced by waterworks. However, as noted above, citizens do not trust urban water quality and instead are willing to pay for expensive bottled water and/or take a tiresome walk to a CDW facility (Kim et al., 2011).

Fig. 3 shows the detailed distribution of CDW facilities in GG Province (27 cities and four counties). Most of the total $431 \mathrm{CDW}$ facilities are distributed in a circular pattern around Seoul, and they are mostly located within a 1-h drive from Seoul (Fig. 3(a)). However, it is important to note that many CDW facilities are not reported to the administrative authorities and are therefore not identified in the official data. Fig. 3(b) shows CDW facilities with their topographic elevations. Most of them ( $>90 \%)$ are situated at elevations of 50-300 m, such as at the entrance to small mountains/hills or to mountain trails (Lee, 2013). Additionally, CDW facilities are generally located near local small rivers and streams (Fig. 3(c)). Considering that the amount of water flowing from CDW facilities increases in the wet season, and the electrical conductivity of CDW decreases at the same time, we infer that the water supply is largely dependent on rainfall as interflow rather than water table percolation (Arno et al., 1998; Jeelani et al., 2010; Goncalves et al., 2013). Fig. 3(d) shows the distribution of CDW facilities according to land use, indicating that many are situated in mountain forests. Therefore, Koreans expect that these sources are very clean and free from anthropogenic contamination. However, CDW sources do suffer from natural contamination related 

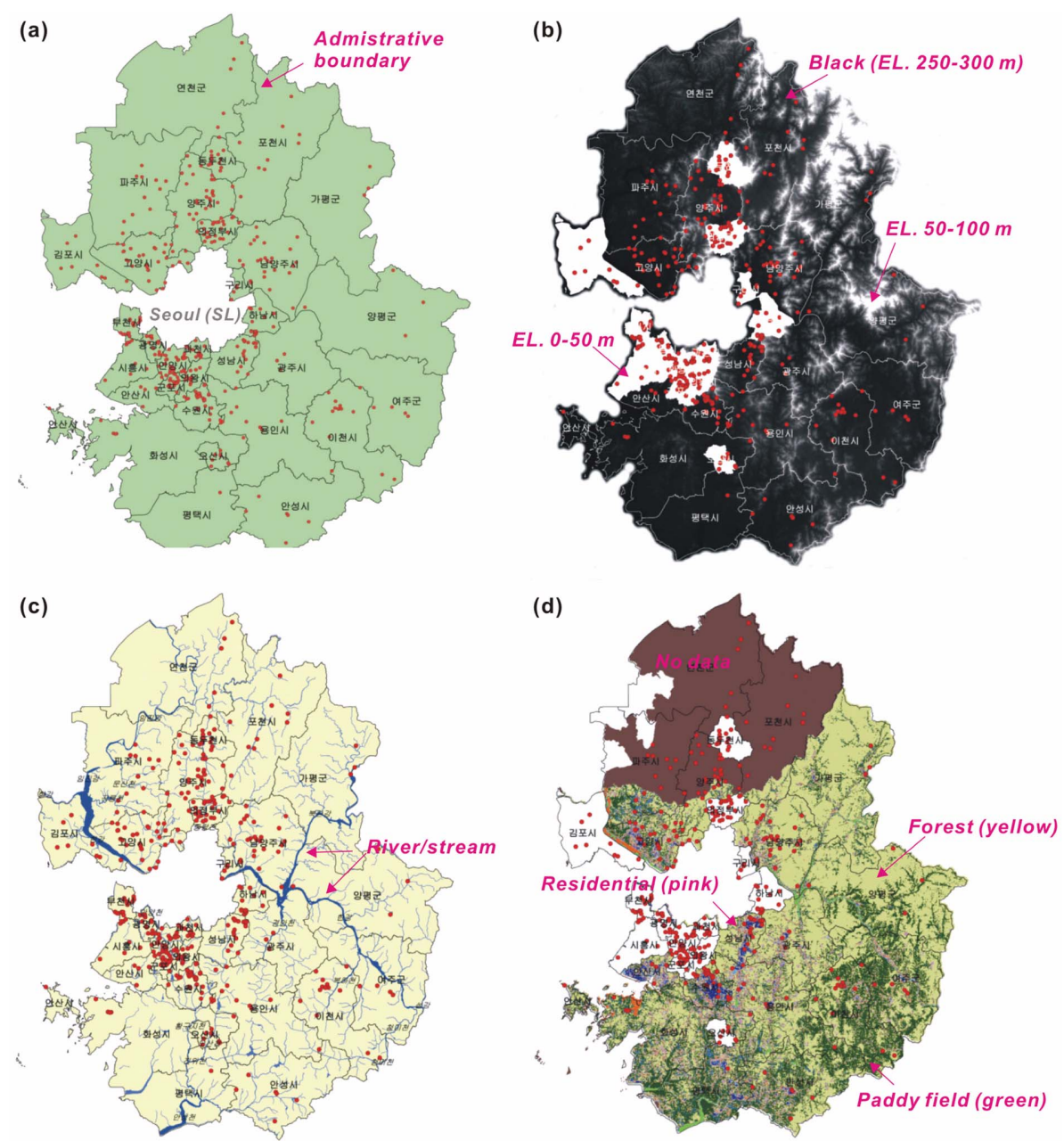

Fig. 3. Distribution of CDW facility with (a) administrative boundary, (b) topographic elevation, (c) river/stream and (d) land use.

to indigenous geology and from also anthropogenic contamination due mainly to the absence of maintenance (Kim et al., 1977; Yun and Jeong, 1983; Jeong et al., 2002; Kim et al., 2008).

\subsection{Physical and Chemical Parameters of CDW}

Fig. 4 shows field measured parameters including water temperature (T), $\mathrm{pH}$, Eh, dissolved oxygen (DO), total dissolved solids (TDS), and electrical conductivity (EC). Water temperature ranged from 1.0 to $22.5^{\circ} \mathrm{C}$, with a mean of $14.6^{\circ} \mathrm{C}$ (Fig. 4(a)). Much lower $\left(<10^{\circ} \mathrm{C}\right)$ and higher $\left(>18^{\circ} \mathrm{C}\right)$ water temperatures were attributed to the effects of outdoor air temperature because the naturally flowing water is directly exposed to the atmosphere. The mean water temperature was within the range of shallow groundwater temperatures (Park et al., 2011b). The pH showed a very wide range between 2.4 and 8.3 , but its mean was slightly acidic (pH 6.1) (Fig. 4(b)). The Korean drinking water $\mathrm{pH}$ standard is $5.8-8.5$, and $18.5 \%$ of CDWs were outside this range. However, this water has been popularly used without any control by Korean people (Kim et al., 2001). Very acidic water sources are generally attributed to enriched $\mathrm{CO}_{2}$ originating from the deep subsurface (igneous host rocks) and/or the dissolution of carbonate minerals in shallow surrounding sedimentary rocks (Kim et al., 2002; Jeong et al., 2011). This carbonic acidic water (high $\mathrm{PCO}_{2}$ ) is a favorite $\mathrm{CDW}$ in Korea because it is believed to aid in food digestion and to cure gastritis (Jeong et al., 2011). However, the excess and long-term consumption of highly acidic water is not thought to be good for people's health, much like very low pH soda water (Tahmassebi et al., 2004; Warren et al., 2009).

Figs. 4(c) and 4(d) show the Eh and DO of CDW. Values 

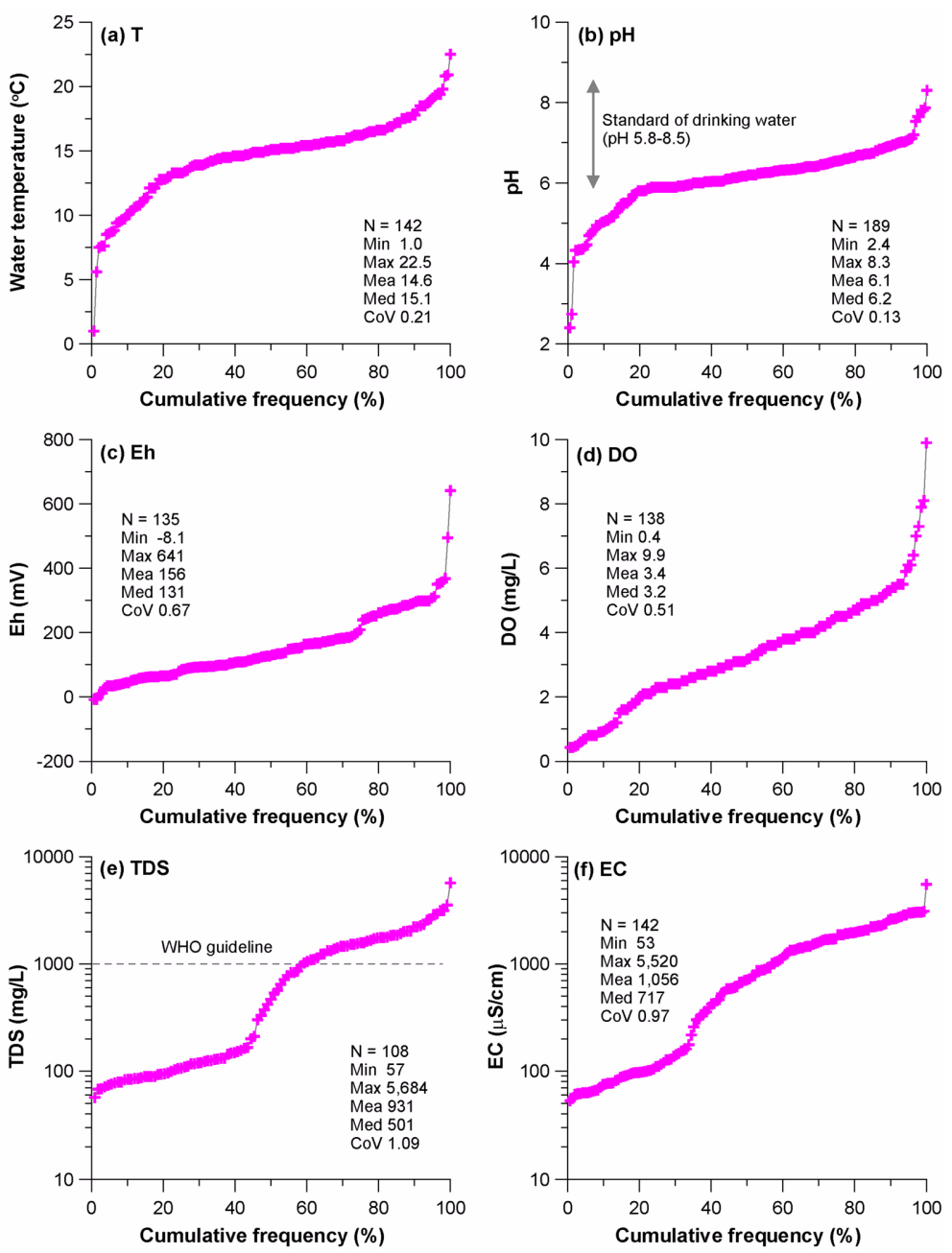

Fig. 4. Cumulative probability plot of field measured parameters (water temperature, $\mathrm{pH}, \mathrm{Eh}, \mathrm{EC}, \mathrm{TDS}$ and DO).

of Eh range from -8.1 to $641 \mathrm{mV}$ with a mean of $156 \mathrm{mV}$, and those of DO range between 0.4 and $9.9 \mathrm{mg} / \mathrm{L}$ with a mean of $3.4 \mathrm{mg} / \mathrm{L}$. Negative or low Eh with a depressed DO indicate that $\mathrm{CDW}$ originate from deep groundwaters, whereas very high positive Eh values with high DO values (>1 mg/L) indicate mixing with shallow groundwaters and/ or the continuous exposure of CDWs to outside air. Both TDS and EC showed similar distributions (Figs. 4(e) and 4(f)) because they are inherently and closely correlated (Walton, 1989). More specifically, TDS showed a range between 57 and $5,684 \mathrm{mg} / \mathrm{L}$ with a mean of $931 \mathrm{mg} / \mathrm{L}$, and EC had a range between 53 and $5,520 \mu \mathrm{S} / \mathrm{cm}$ with a mean of $1,056 \mu \mathrm{S} / \mathrm{cm}$. Very high TDS and EC values indicate that most CDWs are highly enriched with various dissolved constituents including $\mathrm{Ca}, \mathrm{Ng}, \mathrm{Na}, \mathrm{Si}$, and $\mathrm{HCO}_{3}$. According to
WHO guideline (1,000 mg/L) for TDS (WHO, 2003), about $42 \%$ of CDWs exceeded this standard, although Korea has no guideline for TDS.

Fig. 5 shows cumulative probability distributions of some major cations including calcium $(\mathrm{Ca})$, magnesium $(\mathrm{Mg})$, hardness, sodium $(\mathrm{Na})$, potassium $(\mathrm{K})$, and silicon $(\mathrm{Si})$. Concentrations of $\mathrm{Ca}$ ranged from 0.6 to $673.5 \mathrm{mg} / \mathrm{L}$ with a mean of $87.73 \mathrm{mg} / \mathrm{L}$, and it was the most dominant cation. Considering that the surrounding geology of CDW facilities was found to be mostly granite and granitic gneiss, the $\mathrm{Ca}$ likely originated from weathering of silicate minerals (Hem, 1985; Lakshmanan et al., 2003). Very high Ca levels can cause concretions in the kidneys or irritation of the urinary tract (Magesh and Chandrasekar, 2013). Mg was also present in CDW at substantial concentrations between 0.32 

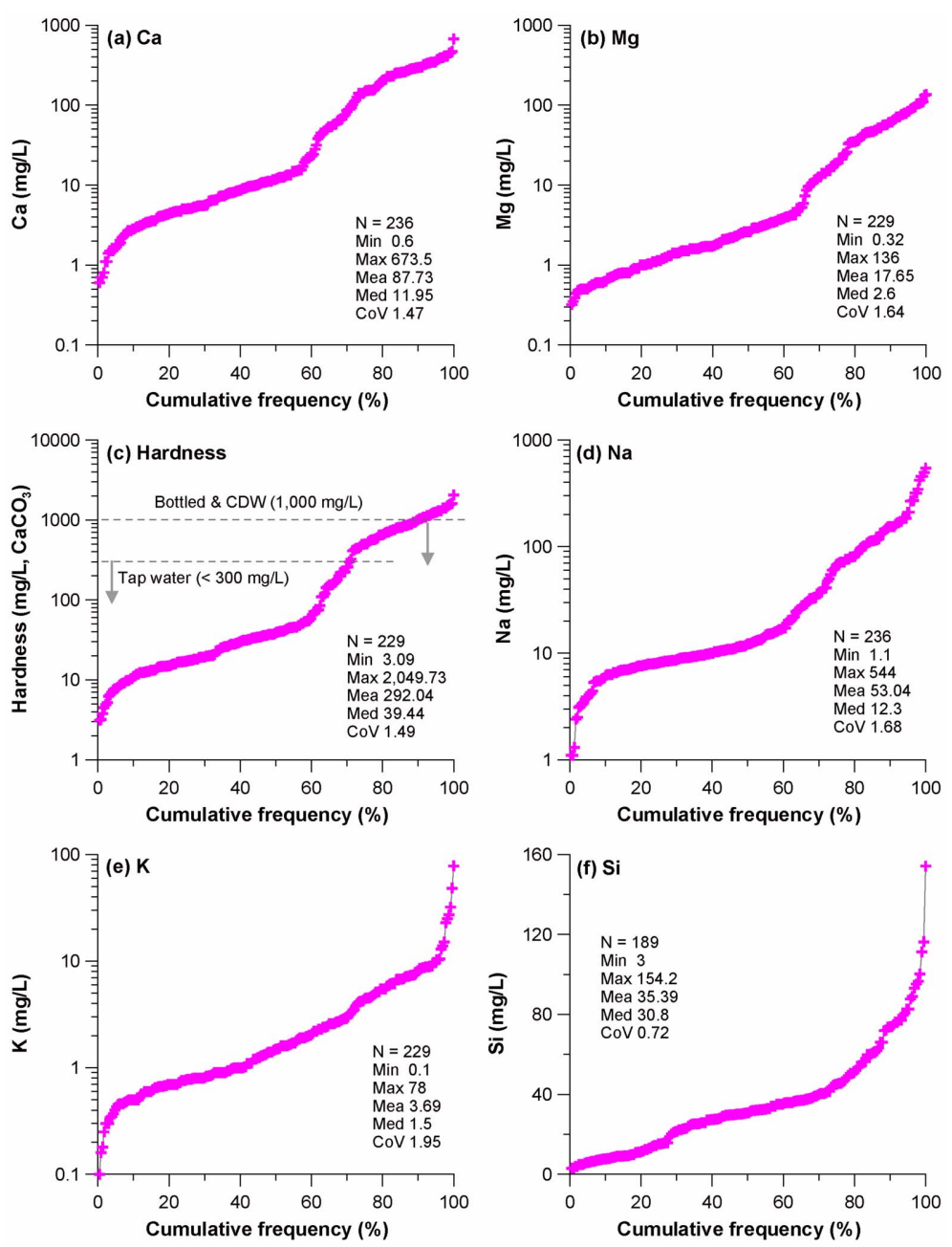

Fig. 5. Cumulative probability plot of some major cations ( $\mathrm{Ca}, \mathrm{Mg}$, hardness, $\mathrm{Na}, \mathrm{K}$ and $\mathrm{Si}$ ).

and $136 \mathrm{mg} / \mathrm{L}($ mean $=17.65 \mathrm{mg} / \mathrm{L})$ and was the fourth most abundant cation. Although there are no drinking water regulations for either $\mathrm{Ca}$ or $\mathrm{Mg}$ ion in Korea, hardness (permanent), represented by $\mathrm{Ca}$ and $\mathrm{Mg}$, has a guideline of 1,000 $\mathrm{mg} / \mathrm{L}$ (as $\mathrm{CaCO}_{3}$ ) for $\mathrm{CDW}$, and about $10 \%$ of $\mathrm{CDW}$ exceeded this guideline. However, water hardness is not generally considered a parameter related to severe health problems (WHO, 2011) even though high Mg levels may cause a laxative effect (Magesh and Chandrasekar, 2013).

Sodium was the second most abundant cation after calcium, with a range between 1.1 and $544 \mathrm{mg} / \mathrm{L}$ (mean $=53.04$ $\mathrm{mg} / \mathrm{L}$ ). Very high enrichment of $\mathrm{Na}$ compared with $\mathrm{Cl}$ (mostly below the $1: 1$ equiline in a $\mathrm{Na}$ vs. $\mathrm{Cl}$ scatter plot; not shown) indicated that $\mathrm{Na}$ is released mainly from the silicate weathering process, not from halite dissolution (Lakshmanan et al., 2003; Kumar et al., 2006; Srinivasamoorthy et al., 2008). There is no standard for $\mathrm{Na}$ concentrations in Korea. Potassium was the least abundant among the major cations, and its concentrations ranged from 0.1 and $78 \mathrm{mg} / \mathrm{L}$ with a mean of $3.69 \mathrm{mg} / \mathrm{L}$ (Fig. 5(e)), and silicon was found in largely elevated concentrations between 3 and $154.2 \mathrm{mg} / \mathrm{L}$ $($ mean $=35.39 \mathrm{mg} / \mathrm{L})$. However, as with $\mathrm{Na}$, there are no standards for drinking water levels of $\mathrm{K}$ or $\mathrm{Si}$ in groundwater because they are not expected to raise particular health issues.

Fig. 6 shows cumulative distribution plots for the major anions of CDW. The abundance of anions was in the order bicarbonate $\left(\mathrm{HCO}_{3}\right)>$ sulfate $\left(\mathrm{SO}_{4}\right)>$ chloride $(\mathrm{Cl})>$ nitrate $\left(\mathrm{NO}_{3}\right)>$ fluoride $(\mathrm{F}) . \mathrm{F}$ is the least abundant anion (0.05-39 $\mathrm{mg} / \mathrm{L}$ ); however, approximately $11 \%$ of CDWs exceeded the Korean standard $(2 \mathrm{mg} / \mathrm{L})$. Frequent ingestion of groundwater containing high concentration of fluoride can cause fluo- 

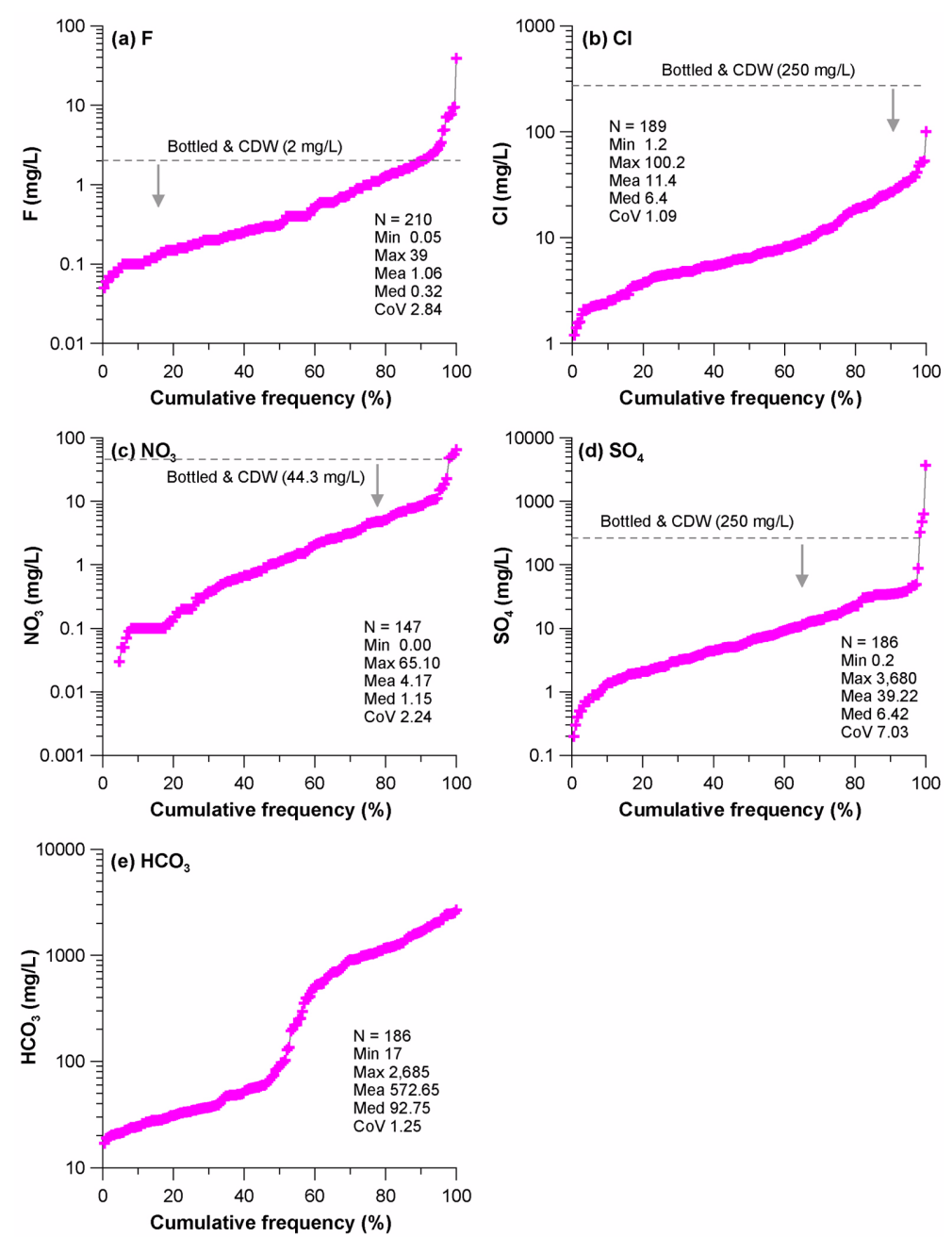

Fig. 6. Cumulative probability plot of some major anions ( $\left.\mathrm{F}, \mathrm{Cl}, \mathrm{NO}_{3}, \mathrm{SO}_{4}, \mathrm{HCO}_{3}\right)$.

rosis. The main source of fluoride is likely weathering of granite or granitic gneiss containing fluoride minerals (Singh et al., 2011; Avtar et al., 2013). Chloride was slightly enriched, ranging between 1.2 and $100.2 \mathrm{mg} / \mathrm{L}$ (mean $=11.4$ $\mathrm{mg} / \mathrm{L}$ ); however, the tested CDWs did not exceed the Korean chloride standard $(250 \mathrm{mg} / \mathrm{L})$. Chloride is an indicator of anthropogenic pollution, and therefore, these relatively low levels of chloride indicate that CDW is generally not affected by residential waste and sewage or industrial wastewater because many CDW facilities are located at a distance from main residential communities.

Levels of nitrate ranged from 0.00 to $65.10 \mathrm{mg} / \mathrm{L}$ with a mean of $4.17 \mathrm{mg} / \mathrm{L}$. Considering the Korean drinking water standard of $44.3 \mathrm{mg} / \mathrm{L}$ for $\mathrm{NO}_{3}\left(10 \mathrm{mg} / \mathrm{L}\right.$ as $\left.\mathrm{NO}_{3}-\mathrm{N}\right)$ and the average high levels $(>>44.3 \mathrm{mg} / \mathrm{L})$ of nitrate in the agricul- tural and residential areas of Korea (Choi et al., 2007; Kaown et al., 2009), the levels in CDWs were generally low, and only $2.7 \%$ exceeded the standard. Similar to chloride, these low levels of nitrate also indicate little anthropogenic contamination from sources such as fertilizers, manures, and wastewater (Williams et al., 1998; WHO, 2011). The sulfate concentrations were high $(0.2-3,680 \mathrm{mg} / \mathrm{L})$ and the second most abundant measured constituent (mean $=39.22 \mathrm{mg} / \mathrm{L}$ ). However, because the drinking water standard for sulfate is very high $(250 \mathrm{mg} / \mathrm{L})$, only $2.1 \%$ of CDW samples exceeded the Korean standard. Even though sulfate is not likely to cause severe health risks, very high drinking water sulfate concentrations $(327.5-3,680 \mathrm{mg} / \mathrm{L})$, associated with oxidation of sulfide minerals (Kim et al., 2002), may produce gastrointestinal effects (WHO, 2011). 
Table 3. Correlation between physicochemical parameters of community drinking water $(n=74)$. Correlation in the lower triangle; probability uncorrelated in the upper triangle. High correlation values $(>0.5)$ are in bold

\begin{tabular}{lccccccccccccccc}
\hline \hline & $\mathbf{T}$ & $\mathbf{p H}$ & $\mathbf{E h}$ & $\mathbf{E C}$ & $\mathbf{D O}$ & $\mathbf{C a}$ & $\mathbf{M g}$ & $\mathbf{N a}$ & $\mathbf{K}$ & $\mathbf{S i}$ & $\mathbf{F}$ & $\mathbf{C l}$ & $\mathbf{N O}_{3}$ & $\mathbf{S O}_{\mathbf{4}}$ & $\mathbf{H C O}_{\mathbf{3}}$ \\
\hline $\mathrm{T}$ & - & 0.444 & 0.001 & 0.003 & 0.034 & 0.000 & 0.000 & 0.464 & 0.174 & 0.530 & 0.175 & 0.837 & 0.941 & 0.006 & 0.000 \\
$\mathrm{pH}$ & -0.09 & - & 0.194 & 0.118 & 0.004 & 0.132 & 0.204 & 0.401 & 0.609 & 0.567 & 0.489 & 0.985 & 0.881 & 0.244 & 0.166 \\
$\mathrm{Eh}$ & 0.37 & -0.15 & - & 0.000 & 0.000 & 0.000 & 0.000 & 0.000 & 0.000 & 0.002 & 0.006 & 0.008 & 0.868 & 0.225 & 0.000 \\
$\mathrm{EC}$ & -0.20 & 0.10 & -0.26 & - & 0.003 & 0.000 & 0.000 & 0.000 & 0.000 & 0.000 & 0.043 & 0.000 & 0.490 & 0.018 & 0.000 \\
$\mathrm{DO}$ & 0.25 & 0.32 & 0.46 & -0.34 & - & 0.001 & 0.006 & 0.076 & 0.398 & 0.349 & 0.278 & 0.346 & 0.650 & 0.035 & 0.000 \\
$\mathrm{Ca}$ & -0.46 & 0.18 & $\mathbf{- 0 . 7 0}$ & $\mathbf{0 . 8 1}$ & -0.37 & - & 0.000 & 0.031 & 0.001 & 0.000 & 0.746 & 0.003 & 0.859 & 0.017 & 0.000 \\
$\mathrm{Mg}$ & -0.48 & 0.15 & $\mathbf{- 0 . 6 5}$ & $\mathbf{0 . 9 0}$ & -0.32 & $\mathbf{0 . 8 2}$ & - & 0.007 & 0.000 & 0.005 & 0.465 & 0.000 & 0.527 & 0.057 & 0.000 \\
$\mathrm{Na}$ & 0.09 & 0.09 & -0.47 & $\mathbf{0 . 6 1}$ & -0.21 & 0.25 & 0.31 & - & 0.000 & 0.000 & 0.000 & 0.030 & 0.886 & 0.270 & 0.000 \\
$\mathrm{~K}$ & -0.16 & 0.06 & -0.41 & $\mathbf{0 . 5 3}$ & -0.10 & 0.37 & 0.45 & $\mathbf{0 . 5 1}$ & - & 0.001 & 0.024 & 0.021 & 0.641 & 0.538 & 0.000 \\
$\mathrm{Si}$ & -0.07 & -0.07 & -0.34 & $\mathbf{0 . 5 4}$ & -0.11 & 0.44 & 0.32 & $\mathbf{0 . 6 3}$ & 0.37 & - & 0.000 & 0.106 & 0.443 & 0.821 & 0.000 \\
$\mathrm{~F}$ & 0.16 & 0.08 & -0.31 & 0.24 & -0.13 & -0.04 & -0.09 & $\mathbf{0 . 7 6}$ & 0.26 & $\mathbf{0 . 5 8}$ & - & 0.957 & 0.445 & 0.651 & 0.031 \\
$\mathrm{Cl}$ & -0.02 & 0.00 & -0.30 & $\mathbf{0 . 5 1}$ & -0.11 & 0.34 & $\mathbf{0 . 5 2}$ & 0.25 & 0.27 & 0.19 & -0.01 & - & 0.380 & 0.197 & 0.000 \\
$\mathrm{NO}_{3}$ & -0.01 & 0.02 & 0.02 & 0.08 & -0.05 & 0.02 & 0.07 & -0.02 & -0.05 & -0.09 & -0.09 & 0.10 & - & 0.995 & 0.854 \\
$\mathrm{SO}_{4}$ & 0.31 & 0.14 & -0.14 & 0.27 & 0.24 & 0.28 & 0.22 & 0.13 & 0.07 & 0.03 & -0.05 & 0.15 & -0.00 & - & 0.434 \\
$\mathrm{HCO}_{3}$ & -0.46 & 0.16 & $\mathbf{- 0 . 7 7}$ & $\mathbf{0 . 9 5}$ & -0.43 & $\mathbf{0 . 8 6}$ & $\mathbf{0 . 8 8}$ & $\mathbf{0 . 5 9}$ & $\mathbf{0 . 5 7}$ & $\mathbf{0 . 5 6}$ & 0.25 & 0.42 & 0.02 & 0.09 & - \\
\hline
\end{tabular}

Bicarbonate showed the most striking levels at 17 to 2,685 $\mathrm{mg} / \mathrm{L}($ mean $=572.65 \mathrm{mg} / \mathrm{L})$. Most Koreans like to drink carbonated water (water containing high $\mathrm{CO}_{2}$ ) because they believe that the carbonated water helps to digest foods (Jeong et al., 2012). Korea has no limit on carbonate in CDW (500 mg/L in India); however, the excessive consumption of water with very high bicarbonate levels in the service of better health has no solid scientific basis (Lee, 2013). High bicarbonate water occurs mostly in granitic areas and thus would originate from silicate mineral alteration, not from dissolution of carbonate minerals (Chae et al., 2006).

\subsection{Correlations between Parameters}

Table 3 shows the Pearson correlation coefficients between the physical and chemical parameters of CDW. Water temperature and $\mathrm{pH}$ did not show any substantial correlation with any parameter. However, Eh showed a significant and negative correlation with $\mathrm{Ca}, \mathrm{Mg}$, and $\mathrm{HCO}_{3}(\mathrm{r}=-0.77$ to 0.65 ). Considering that there were very high positive correlations among the latter three parameters $(\mathrm{Ca}$ and $\mathrm{Mg}$ : $\mathrm{r}=0.82, \mathrm{Ca}$ and $\mathrm{HCO}_{3}: \mathrm{r}=0.86, \mathrm{Mg}$ and $\mathrm{HCO}_{3}: \mathrm{r}=0.88$ ), this indicates that the three parameters behave similarly and that they were derived from the same origin or mechanism, such as silicate mineral alteration in the deep subsurface. As generally expected, EC showed moderate to high positive correlations with most of parameters including $\mathrm{Ca}(\mathrm{r}=0.81)$,
$\mathrm{Mg}(\mathrm{r}=0.90), \mathrm{Na}(\mathrm{r}=0.61), \mathrm{K}(\mathrm{r}=0.53), \mathrm{Si}(\mathrm{r}=0.54), \mathrm{Cl}$ $(\mathrm{r}=0.51)$, and $\mathrm{HCO}_{3}(\mathrm{r}=0.95)$. Na showed significant positive correlations with $\mathrm{Si}(\mathrm{r}=0.63), \mathrm{F}(\mathrm{r}=0.76)$, and $\mathrm{HCO}_{3}$ $(\mathrm{r}=0.59)$. These results again indicate that fluoride (similar to $\mathrm{HCO}_{3}$ ) may be derived from weathering of fluorine-bearing silicate minerals (Subba Rao and Devadas, 2003).

\subsection{Status and Water Quality Index}

Fig. 7 shows some selected diagrams revealing the water status and origin of CDW. The first is a plot of $\mathrm{pH}$ versus Eh (Fig. 7(a)) with CDWs plotted in regions B and C, indicating that these waters are under transitional to slightly reduced environmental exposure, with little direct and continuous contact with outdoor air, meaning they are mostly from shallow or deep groundwaters (Bass Becking et al., 1960). Chemical compositions are illustrated in Fig. 7(b). Most CDWs (80.8\%) were $\mathrm{Ca}-\mathrm{HCO}_{3}$ type, and a few $(17.7 \%)$ were $\mathrm{Na}-\mathrm{HCO}_{3}$ type. The $\mathrm{Ca}-\mathrm{HCO}_{3}$ type is a typical characteristic of shallow groundwaters; however, the number of water sources plotted in the transitional zone between $\mathrm{Ca}-\mathrm{HCO}_{3}$ and $\mathrm{Na}-\mathrm{HCO}_{3}$ indicates that these waters are largely experiencing silicate alteration (weathering) in the deep subsurface (Toran and Saunders, 1999; Rajmohan and Elango, 2004; Jalali, 2007). The Gibbs diagram gives information on the predominance of water-rock interactions (weathering), evaporation, or precipitation in water chemis- 

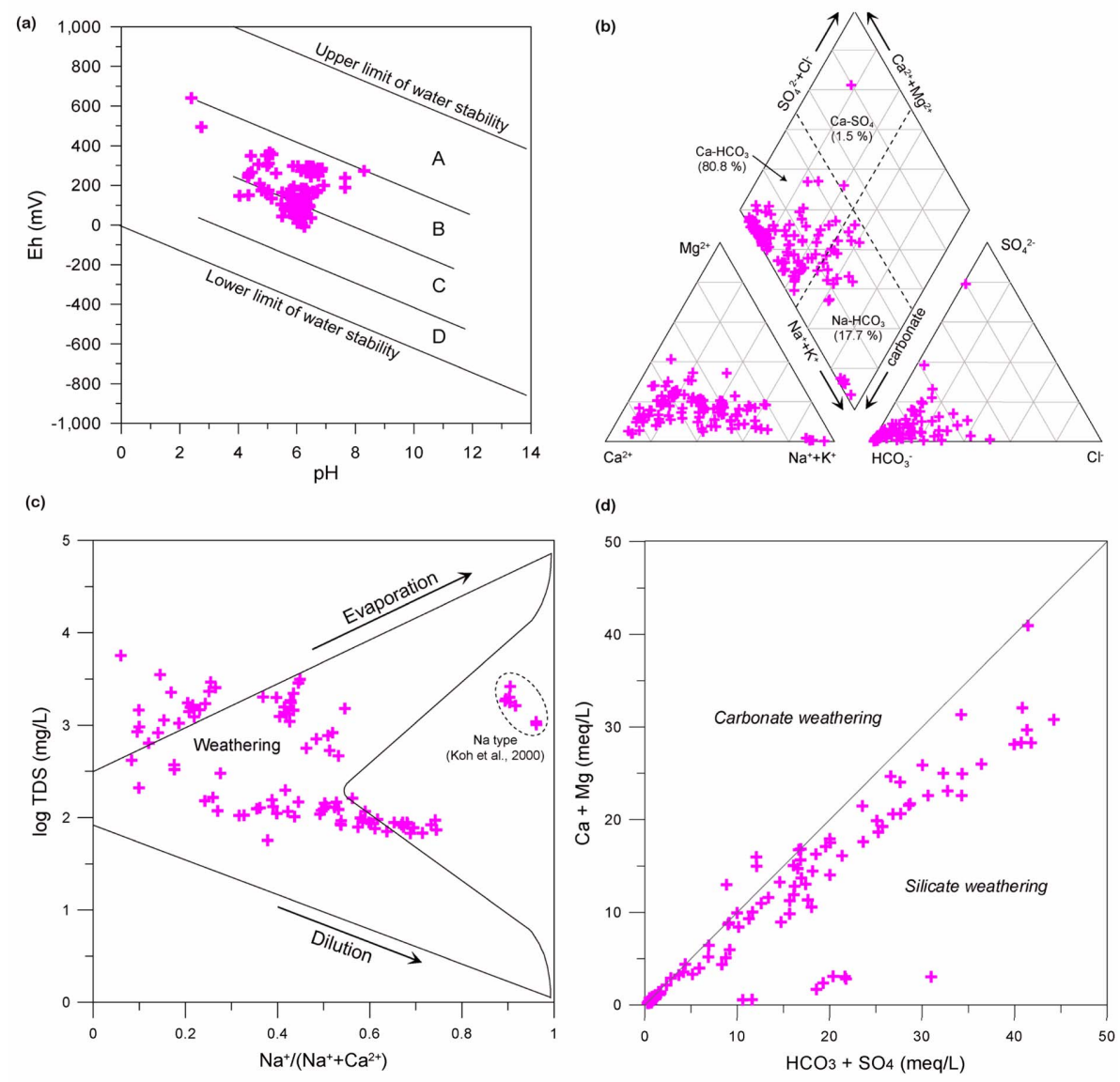

Fig. 7. Redox condition and chemical composition of community drinking waters in Korea $(n=236)$.

try (Kumar et al., 2009), and Fig. 7(c) shows that the interaction between surrounding rock and groundwater is the dominant factor in these waters. Furthermore, a plot of $\mathrm{HCO}_{3}+\mathrm{SO}_{4}$ versus $\mathrm{Ca}+\mathrm{Mg}$ (Fig. 7(d)) further demonstrates that silicate weathering prevails over carbonate weathering.

Fig. 8 shows a classification of CDWs with respect to water taste and health effects using chemical composition based on $\mathrm{O}$ and $\mathrm{K}$ indices by Hashimoto et al. (1987). The O and $\mathrm{K}$ indices were expressed as $\mathrm{O}$ index $=\left[\mathrm{Ca}+\mathrm{K}+\mathrm{SiO}_{2}\right]$ / $\left[\mathrm{Mg}+\mathrm{SO}_{4}\right]$ and $\mathrm{K}$ index $=\mathrm{Ca}-0.87 \mathrm{Na}$. Waters with an $\mathrm{O}$ index over 2.0 and $\mathrm{K}$ index over 5.2 represent tasty and healthful water, respectively (Hashimoto et al., 1987). According to these indices, $48 \%$ of CDWs were classified as both tasty and healthful water, whereas $42 \%$ were neither tasty nor healthful. Although these indices are empirical and somewhat subjective, it may be inferred that a considerable proportion of CDWs in this study are inappropriate to drink with respect to either taste or health concerns.

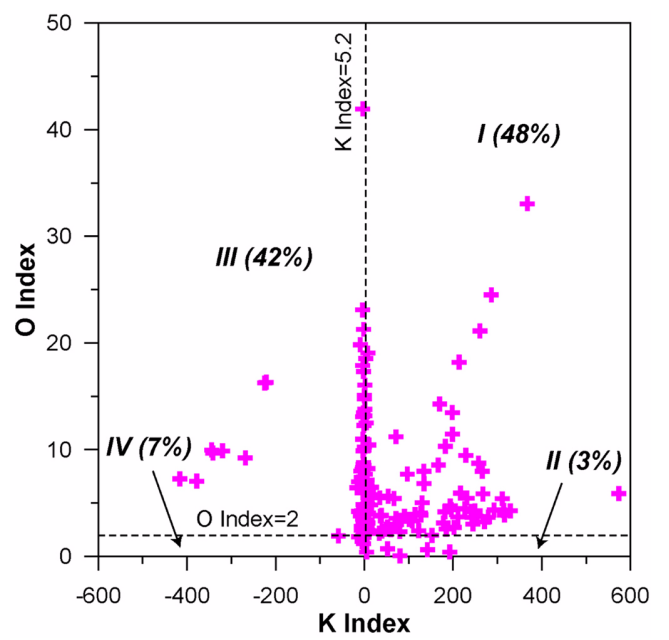

Fig. 8. Classification of carbonic community drinking water $(\mathrm{n}=182)$ using $\mathrm{O}$ and $\mathrm{K}$ indices.

\section{Conclusions and Implications}

Here, we examined characteristics (location, field mea- 
sured parameters, and chemical composition) of some popular CDWs in Korea. Most Koreans believe that these waters are beneficial to their health, mainly due to the presumed pharmacological action of certain constituents that are present in abnormally high concentrations. Especially, high iron (not included in this study) and (bi)carbonate waters have attracted many Korean people. This great dependency on CDWs is largely derived from a distrust of the quality of tap water and surface water. However, the maintenance and control of CDW facilities have been inadequate compared with those of commercial bottled waters. When the CDWs exceed the Korean standards, the relevant environmental authorities post a warning message but generally fail to ban the use of contaminated waters by community people. Therefore, the designation of a private, unofficial (honorary) manager for the proper management of CDWs and the enactment of an effective ban on their use during times of contamination are required. Furthermore, as described above, we do not know whether particular CDWs are medically effective, and thus we need a long-term multidisciplinary research on the actual health effects of CDW consumption.

\section{Acknowledgements}

This research is supported by the Korean Ministry of Environment as "The GAIA project (No. 173-092-010)" and also supported by 2013 Research Grant from Kangwon National University (No. 1010250-01-01).

\section{References}

Arno, K., Lindemann, J., Schellenberger, A., Beierkuhnlein, C., Kaupenjohann, M., and Peiffer, S., 1998, Slope deposits and water paths in a spring catchment, Frankenwald, Bavaria, Germany, Nutr. Cycling Agroecosyst., 50, 119-126.

Avtar, R., Kumar, P., Surjan, A., Gupta, L.N., and Roychowdhury, K., 2013, Geochemical processes regulating groundwater chemistry with special reference to nitrate and fluoride enrichment in Chhatarpur area, Madhya Pradesh, India, Environ. Earth Sci. (in press).

Baas Becking, L.G.M., Kaplan, I.R., and Moore, D., 1960, Limits of the natural environment in terms of $\mathrm{pH}$ and oxidationreduction potentials, J. Geol., 68, 243-284.

J. Soil \& Groundwater Env. Vol. 18(6), p. 56 68, 2013
Chae, G.T., Yun, S.T., Kim, K., and Mayer, B., 2006, Hydrogeochemistry of sodium-bicarbonate type bedrock groundwater in the Pocheon spa area, South Korea: water-rock interaction and hydrologic mixing, J. Hydrol., 321, 326-343.

Choi, D.K., Woo, J., and Park, T.H., 2012, The Okcheon Supergroup in the Lake Chungju area, Korea: Neoproterozoic volcanic and glaciogenic sedimentary successions in a rift basin, Geosci. J., 16(3), 229-252.

Choi, W.J., Han, G.H., Lee, S.M., Lee, G.T., Yoon, K.S., Choi, S.M., and Ro, H.M., 2007, Impact of land-use types on nitrate concentration and $\delta^{15} \mathrm{~N}$ in unconfined groundwater in rural areas of Korea, Agric. Ecosyst. Environ., 120, 259-268.

GIMS (Ground Water Information Service), 2013, Use of water resources in Korea, http://www.gims.go.kr.

Goncalves, T.D., Fischer, T., Grabe, A., Kolditz, O., and Weiss, H., 2013, Groundwater flow model of the Pipiripau watershed, Federal District of Brazil, Environ. Earth Sci., 69(2), 617-631.

Hashimoto, S., Fujita, M., Furukawa, K., and Minami, J.I., 1987, Indices of drinking water concerned with taste and health, J. Ferment. Technol., 65, 185-192.

Hem, J.D., 1985, Study and interpretation of the chemical characteristics of natural water, USGS, Alexandria, VA.

Jalali, M., 2007, Salinization of groundwater in arid and semiarid zones: an example from Tajarak, western Iran, Environ. Geol., 52, 1133-1149.

Jeelani, G., Bhat, N.A., and Shivanna, K., 2010, Use of 180 tracer to identify stream and spring origins of a mountainous catchment: A case study from Liddar watershed, Western Himalaya, India, J. Hydrol., 393(3-4), 257-264.

Jeong, C.H. and Jeong, G.Y., 1999, Geochemical water quality and genesis of carbonated Dalki mineral water in the Chungsong area, Kyungpook, Econ. Environ. Geol., 32(5), 455-468 (in Korean with English abstract).

Jeong, C.H., Kim, K.H., and Nagao, K., 2012, Hydrogeochemistry and origin of $\mathrm{CO}_{2}$ and noble gases in the Dalki carbonate waters of the Chungson area, J. Eng. Geol., 22(1), 123-134 (in Korean with English abstract).

Jeong, C.H., Park, C.H., and Lee, K.S., 2002, Water quality and hydrochemistry of natural springs and community wells in Daejeon area, Econ. Environ. Geol., 35(5), 395-406 (in Korean with English abstract).

Jeong, C.H., Yoo, S.W., Kim, K.H., and Nagao, K., 2011, Hydrochemistry and origin of noble gases and $\mathrm{CO}_{2}$ gas within carbonated mineral waters in the Kyeoungbuk-Kangwon Province, Korea, J. Eng. Geol., 21(1), 65-77 (in Korean with English abstract).

Jung, I.W., Chang, H., and Bae, D.H., 2013, Spatially-explicit assessment of flood risk caused by climate change in South 
Korea, KSCE J. Civil Eng., 17(1), 233-243.

Kaown, D., Koh, D.C., Mayer, B., and Lee, K.K., 2009, Identification of nitrate and sulfate sources in groundwater using dual stable isotope approaches for an agricultural area with different land use (Chuncheon, mid-eastern Korea), Agric. Ecosyst. Environ., 132, 223-231.

Kim, C.S., Park, M.E., and Koh, Y.K., 2002, Isotopic, geochemical and hydrogeological studies on the mineral water in Korea: occurrence, origin and evolution, Korea Science Foundation (in Korean with English summary).

Kim, H.S., Koo, D.S., and Park, Y.W., 1977, Mineral water investigation on 10 area in Seoul, J. Preven. Medic. Public Health, 10(1), 59-61 (in Korean with English abstract).

Kim, I.S., Ha, H., Seo, W.S., Bae, J.S., Mun, H., Park, C.U., Oh, E.H., Lee, S.Y., and Kim, M.H., 1998, A study of water quality characteristic of natural mineral water in Chonnam area, Kor. $J$. Environ. Health Soc., 24(1), 87-97 (in Korean with English abstract).

Kim, G.Y., Koh, Y.K., Bae, D.S., Kim, C.S., and Park, M.E., 2001, Geochemistry and isotope studies of the Shinchon $\mathrm{CO}_{2}$ rich waters in the Gyeongsang Province, Econ. Environ. Geol., 34(1), 71-88 (in Korean with English abstract).

Kim, K.A., Lee, B.O., Kim, O.M., Hur, M.J., Kim, K.T., Ro, J.I., Choe, C.S., Go, J.M., and Kim, Y.H., 2008, A study on pollution of spring in Incheon area, Incheon Metro. City Inst. Health Environ., 11, 152-167 (in Korean with English abstract).

Kim, K.R., Gil, H.K., Lee, M.H., Eom, S.W., and Lee, J.Y., 2011, Survey of citizens public opinion for natural spring water in Seoul, J. Soil Groundwater Env, 16(2), 1-5 (in Korean with English abstract).

KMA (Korea Meteorological Administration), 2013, Climate of Korea http://www.kma.go.kr/weather/climate/average_south.jsp.

Ko, E.J., Kim, K.W., Kang, S.Y., Kim, S.D., Bang, S.B., Hamm, S.Y., and Kim, D.W., 2007, Monitoring of environmental phenolic endocrine disrupting compounds in treatment effluents and river waters, Korea, Talanta, 73(4), 674-683.

Ko, Y.K., Kim, C.S., Choi, H.S., Park, M.E., and Bae, D.S., 2000, Geochemical studies of $\mathrm{CO}_{2}$-rich mineral water in the Kangwon Province, J. Kor. Soc. Groundwater Environ., 7(2), 73-88 (in Korean with English abstract).

Koh, Y.K., Kim, C.S., Choi, H.S., Park, M.E., and Bae, D.S., 2000, Geochemical studies of $\mathrm{CO}_{2}$-rich mineral water in the Kangwon Province, J. Kor. Soc. Groundwater Environ., 7(2), 73-88 (in Korean with English abstract).

Kumar, M., Ramanathan, A.L., Rao, M.S., and Kumar, B., 2006, Identification and evaluation of hydrogeochemical processes in the groundwater environment of Delhi, India, Environ. Geol., 50, 1025-1039.
Kumar, S.K., Rammonhan, V., Sahayam, J.D., and Jeevanandam, M., 2009, Assessment of groundwater quality and hydrochemistry of Manimuktha River basin, Tamil Nadu, India, Environ. Monit. Assess., 159, 341-351.

Lakshmanan, E., Kannan, R., and Kumar, M.S., 2003, Major ion chemistry and identification of hydrogeochemical processes of ground water in a part of Kancheepuram district, Tamil Nadu, India, Environ. Geosci., 10(4), 157-166.

Lee, J.Y., 2013, Debate on healthy drinking water in Korea: Belief or science?, Environ. Sci. Europe (submitted).

Lee, J.Y., Jeon, W.H., Park, Y., and Lim, H.G., 2012, Status and prospect of groundwater resources in Pyeongchang, Gangwondo, J. Geol. Soc. Korea, 48(5), 435-444 (in Korean with English abstract).

Lee, J.Y. and Lee, K.K., 2000, Use of hydrologic time series data for identification of recharge mechanism in a fractured bedrock aquifer system, J. Hydrol., 229(3-4), 190-201.

Lee, J.Y., Yi, M.J., Yoo, Y.K., Ahn, K.H., Kim, G.B., and Won, J.H., 2007, A review of the National Groundwater Monitoring Network in Korea, Hydrol. Process., 21, 907-919.

Magesh, N.S. and Chandrasekar, N., 2013, Evaluation of spatial variations in groundwater quality by WQI and GIS technique: a case study of Virudunagar District, Tamil Nadu, India, Arab. J. Geosci., 6, 1883-1898.

Moon, H. and Park, K.H., 1998, Mineral characteristics of spring water in Chonnam, Kor. J. Food Sci. Technol., 30(2), 253-259 (in Korean with English abstract).

Moon, S.H., Hwang, J., Lee, J.Y., Hyun, S.P., Bae, B.K., and Park, Y., 2013, Establishing the origin of elevated uranium concentrations in groundwater near the central Ogcheon metamorphic belt, Korea, J. Environ. Qual., 42, 118-128.

Park, Y., Lee, J.Y., Lim, H.G., and Park, Y.C., 2011a, Characteristics of hydraulic conductivity of carbonate aquifers in Gangwon province, J. Eng. Geol., 21(1), 79-85 (in Korean with English abstract).

Park, Y.C., Jo, Y.J., and Lee, J.Y., 2011, Trends of groundwater data from the Korean National Groundwater Monitoring Stations: indication of any change?, Geosci. J., 15(1), 105-114.

Rajmohan, N. and Elango, L., 2004, Identification and evolution of hydrogeochemical processes in the groundwater environment in an area of the Palar and Cheyyar River Basins, Southern India, Environ. Geol., 46, 47-61.

Seo, K.H. and Ok, J., 2013, Assessing future changes in the East Asian summer monsoon using CMIP3 models: results from the best model ensemble, J. Clim., 26, 1807-1817.

Sim, W.J., Lee, J.W., and Oh, J.E., 2010, Occurrence and fate of pharmaceuticals in wastewater treatment plants and rivers in

J. Soil \& Groundwater Env. Vol. 18(6), p. 56 68, 2013 
Korea, Environ. Pollut., 158(5), 1938-1947.

Singh, C.K., Kumari, R., Singh, R.P., Shashtri, S., Kamal, V., and Mukherjee, S., 2011, Geochemical modeling of high fluoride concentration in groundwater of Pokhran Area of Rajasthan, India, Bull. Environ. Contam. Toxicol., 86, 152-158.

Srinivasamoorthy, K., Chidambaram, S., Prasanna, M.V., Vasanthavihar, M., Peter, J., and Anandhan, P., 2008, Identification of major sources controlling groundwater chemistry from a hard rock terrain-A case study from Mettur taluk, Salem district, Tamil Nadu, India, J. Earth Syst. Sci., 117(1), 49-58.

Subba Rao, N. and Devadas, D.J., 2003, Fluoride incidence in groundwater in an area of Peninsular India, Environ. Geol., 45, 243-251.

Tahmassebi, J.F., Duggal, M.S., Malik-Kotru, G., and Curzon, M.E.J., 2004, Soft drinks and dental health: A review of the current literature, J. Dent., 34, 2-11.

Toran, L.E. and Saunders, J.A., 1999, Modeling alternative paths of chemical evolution of Na-HCO3-type groundwater near Oak Ridge, Tennessee, USA, Hydrogeol. J., 7, 355-364.
Walton, N.R.G., 1989, Electrical conductivity and total dissolved solids-What is their precise relationship?, Desalination, 72(3), 275-292.

Warren, J.J., Weber-Gasparoni, K., Marshall T.A., Drake, D.R., Dehkordi-Vakil, F., Dawson, D.V., and Tharp, K.M., 2009, A longitudinal study of dental caries risk among very young low SES children, Community Dent. Oral, 37(2), 116-122.

WHO (World Health Organization), 2003, Total dissolved solids in drinking-water, WHO, Geneva.

WHO, (World Health Organization), 2011, Guidelines for drinking-water quality, Fourth edition, WHO, Geneva.

Williams, A.E., Lund, L.J., Johnson, J.A., and Kabala, Z.J., 1998, Natural and anthropogenic nitrate contamination of groundwater in a rural community, California, Environ. Sci. Technol., 32, 32-39.

Yun, N.K. and Jeong, B.G., 1983, The investigation of medical water's quality on 9 areas in Taegu city and the suburb area, Med. J. Keimyung Univ., 2(2), 149-152 (in Korean with English abstract). 